See discussions, stats, and author profiles for this publication at: https://www.researchgate.net/publication/327099829

\title{
Energy Situation in the Republic of Serbia
}

Preprint · August 2018

DOI: 10.20944/preprints201808.0279.v1

CITATION

1 author:

Dejan Brkić

VŚB-Technical University of Ostrava

147 PUBLICATIONS 1,015 CITATIONS

SEE PROFILE

Some of the authors of this publication are also working on these related projects:

[JMSE] (SCIE Indexed, IF 1.732)-Invite to Publish in Special Issue "Safe, Secure and Sustainable Oil and Gas Drilling, Exploitation and Pipeline Transport Offshore" View project

Flow friction calculation - Colebrook equation View project
READS

197

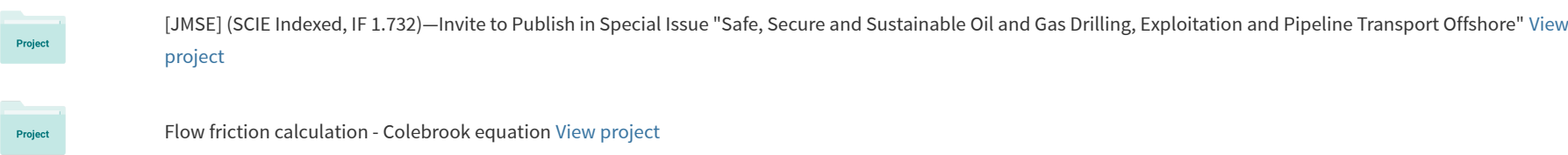




\title{
Energy Situation in the Republic of Serbia
}

\author{
Dejan Brkić \\ Ministry of Science, Strumička 88, Beograd, 11000, Serbia \\ dejanrgf@tesla.rcub.bg.ac.rs,dejanbrkic0611@gmail.com
}

\begin{abstract}
Paper presents the energy policy of the Republic of Serbia with special attention to the energy situation on the government controlled territory. South Serbian autonomous province of Kosovo and Metohija is under UN jurisdiction since the 1999 according to UNSC Resolution 1244. Renewable energy sources are rarely used in Serbia with exception of energy from hydropower plants, but in this sector priorities in geothermal and energy coming from biomass recently increased. In natural gas sector, Serbia has the deal with Russia for construction of South Stream gas-line through Serbia and for construction of the first underground storage in depleted gas reservoir in Banatski Dvor. In 2008, Serbia also sold 51\% of the government founded petroleum industry - NIS which has exclusive monopoly for exploitation of crude oil. Serbian government has complete monopoly in electric power sector. Electric power infrastructure became technologically obsolete, and operative efficiency is at very low level. Serbia has not yet decided whether Serbian Electric Power Industry - EPS will be privatized. District heating sector mostly natural gas fuelled is highly inefficient and it is in jurisdiction of local municipalities but also has social component dictated by central government.
\end{abstract}

Keywords: Serbia, Energy policy, Energy sectors

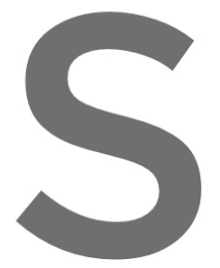

\section{Introduction}

Republic of Serbia is a eastern Europe, covering

Peninsula, between Mont

Bulgaria, Romania, Hungary, Croatia, and Bosnia and Herzegovina. Serbia is a country with a population of 7.498.001 (without autonomous province of Kosovo and Register fogrerdiege alt int Empire. Over the next few decades Serbia operated in all practical matters as an independent nation-state, although formal international recognition did not come until 1878. Serbia became kingdom very soon in 1882, but after the World War I, Serbia was only part of the Kingdom of Yugoslavia until 1945 and until 1990 one of the six communist Yugoslav republics. After short civil war, four republics declared independency from Yugoslavia (Macedonia, Bosnia and Herzegovina, Croatia and Slovenia). Only Serbia and Montenegro stay in union until 2006. Union of Serbia and Montenegro was in 1990s under UN sanctions during 1990's according to UNSC Resolution 757. NATO also bombed Serbia and Montenegro with no UNSC Resolution. In 2006 both republics restored their independency as were before 1918 but only with changed borders and now not as kingdoms. Now, south Serbian autonomous province of Kosovo and Metohija is under UN jurisdiction since the 1999 according to UNSC Resolution 1244. Serbia runs reforms after the democratic changes in 2000 and applied for the membership in EU but still is not official candidate [1].

Energy sector represents a key industrial branch in Serbia. Serbia is an energy deficient country. The

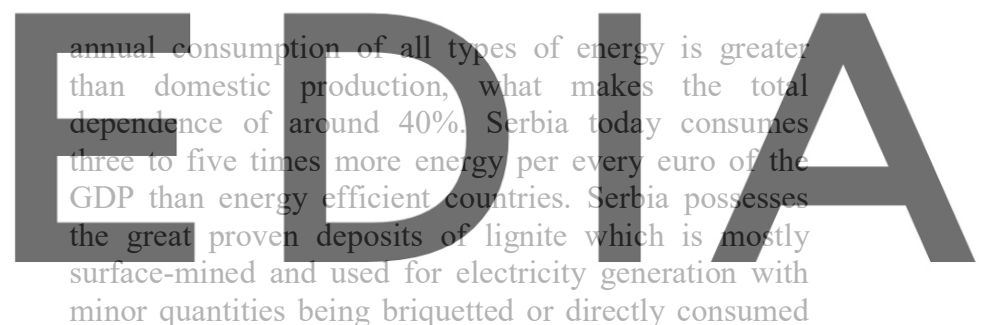

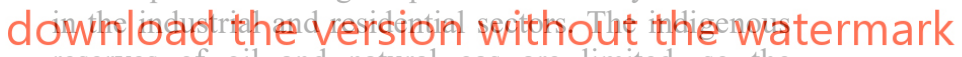

reserves of oil and natural gas are limited, so the country is heavily dependent on the import of crude oil and natural gas. Serbia also signed deal with Russia for the construction of 'South Stream' line which one branch will transmit gas through Serbia for EU market. The oil and gas import bill is a serious strain on the economy of the country. In spite of that, contribution of renewable energy sources in total energy consumption contemporary amounts to less than 1\% (excluding hydro-power). Producing energy from renewable sources in Serbia is in its initial phase. Traditional fuels like firewood, dung and crop residues currently contribute a major share in meeting the everyday energy requirements of rural and low-income urban households. Serbia has god investment potentials in renewable energy sources such as solar energy, wind and geothermal energy or the hydro-potential of small water courses. The largest reserves perhaps lie in the enormous potential of geothermal resources, biomass and biogas.

Serbia ratified Kyoto protocol in 2007 and as seems will be capable to respond adequately to the European rules regarding the substitution of a certain amounts of fossil fuels by the fuel origin from the raw biological materials. 


\section{Fossil fuels in Serbia}

Here will be discussed situation with coal, crude oil and natural gas as most important fuels for energy situation in Serbia.

\subsection{Coal}

The brown coal production in Serbia amounted to over $95 \%$ of the total coal production while the share of soft brown coals (lignite) in that production is $98.7 \%$ and hard brown coals $1.2 \%$ [2]. Values of combustion of Serbian lignite are from 6.7 to $8.3 \mathrm{MJ} / \mathrm{kg}$. Over $90 \%$ of the production of lignite is fired in power plants. Serbia possesses the great proven deposits of lignite (Figure 1):
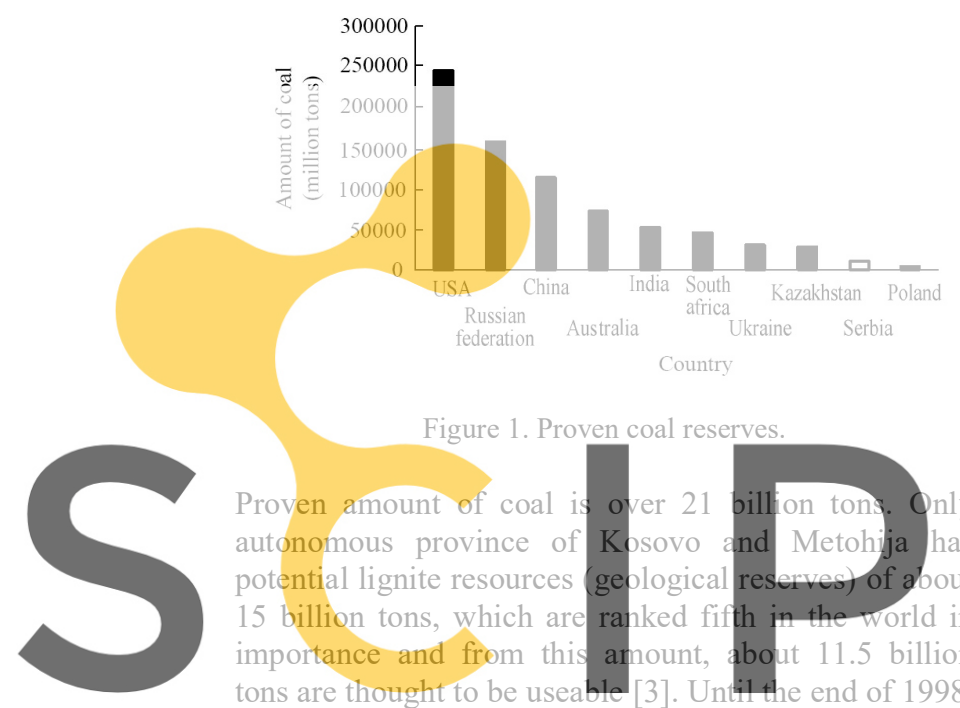

Figure 1. Proven coal reserves.
Proven amount of coal is over 21 bill on tons. Only
autonomous province of Kosovo and Metohija has
potential lignite resources (geological reserves) of about
15 billion tons, which are ranked fifth in the Norld in
importance and from this anount, about 11.5 billion
tons are thought to be useable [3]. Until the end of 1998 ,
about 226 million tons of lignite had been used from

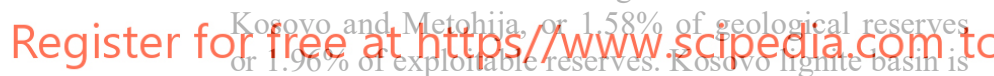
one of the largest coal basins in Europe, formed in the Pliocene era in a surface about $850 \mathrm{~km}^{2}$. Coal is the most significant energy potential in Serbia, with the share of $84 \%$ in the structure of energy reserves [4]. At this moment lignite-fuelled power plants supply over $60 \%$ of electricity in Serbia. Brown coals occur in Serbia in 33 coal basins, but only 11 of them are under exploitation: four are opencast mines, and seven are underground mines; one mine is under the Danube. Main coal production in Serbia is based on two mining basins: 'Kolubara' and 'Kostolac' (as of 1 July 1999, Serbia does not operate their surface mines and power plants on the territory of autonomous province of Kosovo and Metohija). Current capacity of these open cast mines is over 36 million tons of lignite (Figure 2), with over $108 \mathrm{mcm}$ (million cubic meters) of overburden (Figure 3).

Energy and environmental policies on coal mining in Serbia may be divided in several phases. During the 1970 s, after oil crises, supply security was placed in the focus of energy policy. In the course of this period, there was forceful modernization of Serbian open cast mines, purchase of, modern mining machinery. In the second half of $1980 \mathrm{~s}$, environment protection was beginning to gain importance in the energy policy and investments [5].

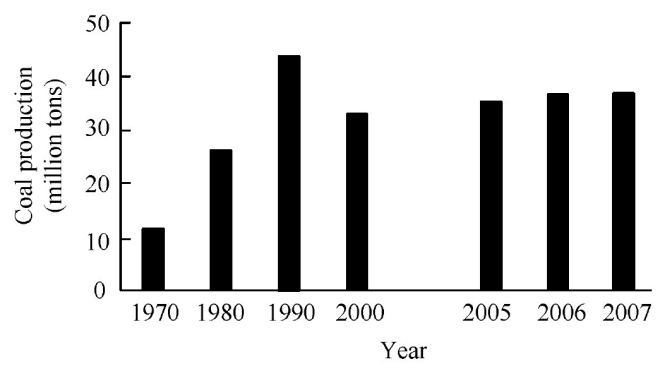

Figure 2. Lignite production in 'Kolubara' and 'Kostolac'.

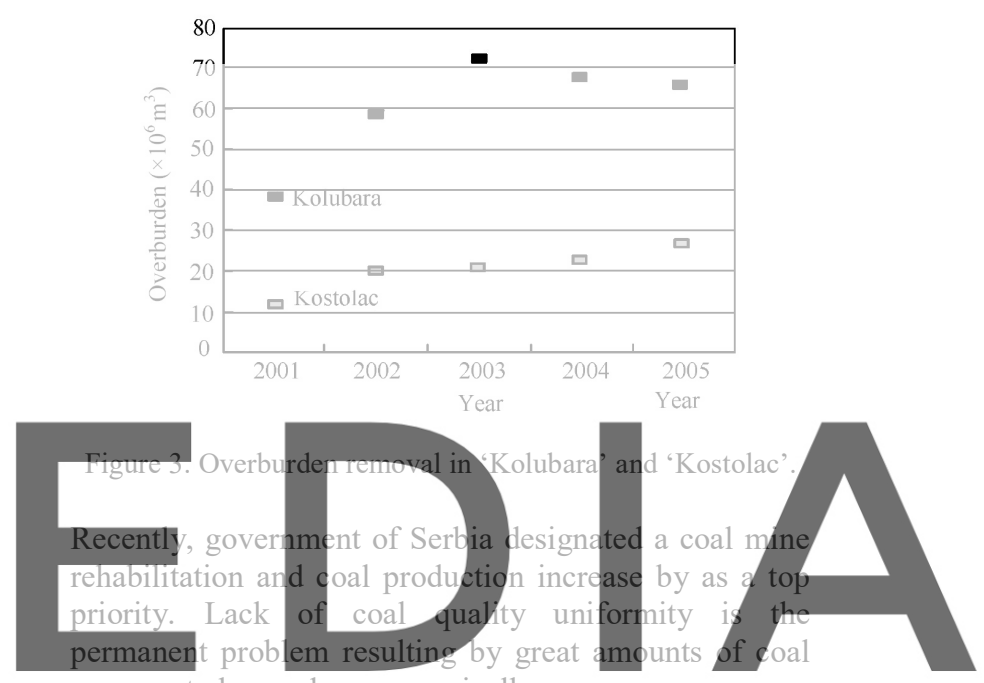
reserves to be used uneconomically.

\section{dớrnilogal the version without the watermark Almost all Serbian oil and gas production is situated north of Danube (Figure 4).}

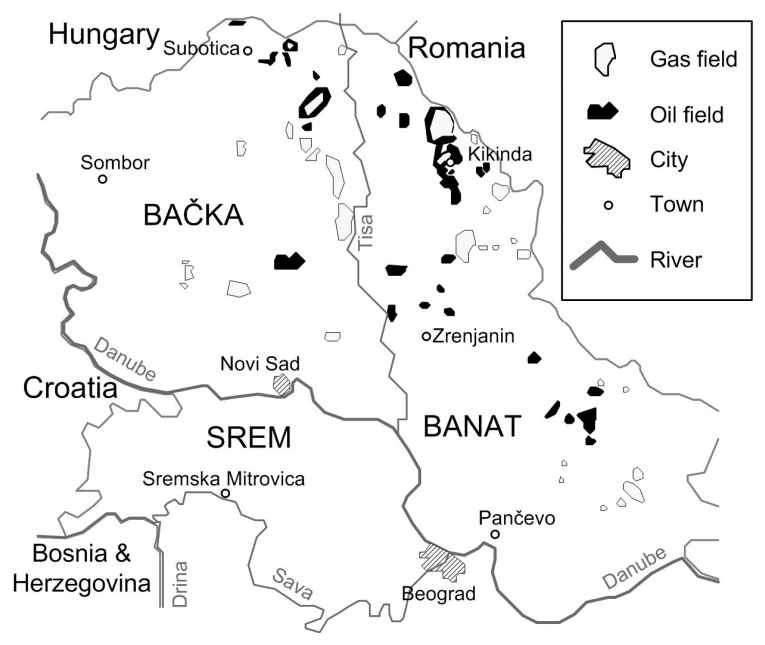

Figure 4. Oil and gas fields in Serbia.

Consumption of all oil products in Serbia is about 3 million tons $37 \%$ of all energy consumption in the country). This is only $50 \%$ of consumption in 1990 . 
Main reason of such decreased consumption lays in substitution of liquid fuel with natural gas for satisfying of heating demands for households [6]. Oil refineries were mostly destroyed in NATO bombing during 1999 . In 2000, Serbian refineries processed and refined about 1 million tons of oil. Main refinery is situated in Pančevo near Belgrade. Rafinery in Pančevo is obsolete and it is great threat for environmental protection. Now, import of final hydrocarbon products are forbidden by government decree. Only crude oil can be imported and then processed and refined in some of Serbian refineries. During 1990s situation was different, i.e. export of oil products including crude oil to Serbia and Montenegro was forbidden by UNSC Resolution 757. Indigenous oil production can cover nearly $25 \%$ of demands for oil. In Serbian oil balance is also included concession from Angola (Table 1).

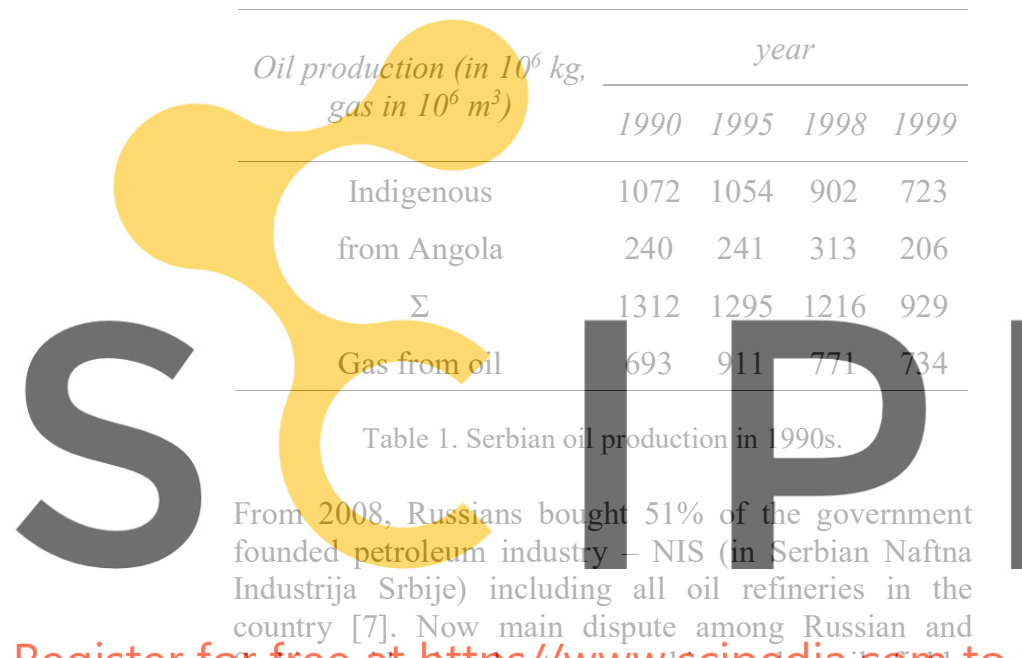

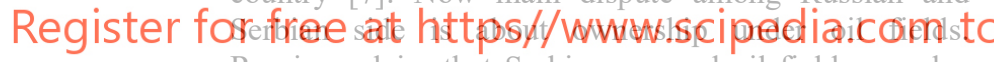
Russians claim that Serbian gas and oil fields are also included in the price for NIS, but Serbian side claims that these fields remain in the formal property of Serbia with Russian obligation to pay a rent. Today, all jobs in petroleum and gas explorations and exploitations are under NIS jurisdiction. There is no place for other private domestic or foreign services companies in this kind of business. All exploitation fields are in government's property and price for crude oil and gas are formed by government decrees according to recommendations from the Serbian Energy Regulatory Agency. Mining tax for NIS is only $3 \%$ and license for monopoly is free for government owned firms since the communist era. Of course, price of crude oil in world's market are irrelevant in relation between NIS and government. International price of crude oil has major role for final price of fuel for vehicles relevant only for final consumers (now adjusted every week).

\subsection{Natural gas}

Gas utilization in Serbia has started sixty years ago. Serbia has produced natural gas domestically, since 1952, but the intensive development of consumption and the gas pipeline system in Serbia started by the import of natural gas from former USSR in 1978. Gas consumption in Serbia showed tendency for continuous growth until 1989 when the greatest consumption was reached, and since then it was declining. Maximum of consumption of gaseous fuels (natural gas) reached in 1989 and amounted to $2.87 \mathrm{bcm}$ (billion cubic meters) while 'Hubert peak' for gas production was in 1993 with $801 \mathrm{mcm}$ during UN blockade under UNSC Resolution 757 (Table 2).

\begin{tabular}{cccccc}
\hline & \multicolumn{5}{c}{ year } \\
$\begin{array}{cccccc}\text { Gas production } \\
\left(10^{6} \mathrm{~m}^{3}\right)\end{array}$ & 1989 & 1993 & 1997 & 1999 & 2004 \\
\cline { 2 - 6 } & 563 & 801 & 589 & 623 & 230 \\
\hline P-Production & & & & & \\
C-Consumption & 2877 & 1080 & 2629 & 1697 & 2481 \\
P/C $(\%)$ & 19.6 & 74.2 & 22.4 & 36.7 & 9.3 \\
\hline
\end{tabular}

Table 2. Serbian natural gas production and consumption.

The share of gaseous fuels in total consumption was equal to $13 \%$, i.e. $17 \%$ in final energy consumption. Industry plays dominant role in Serbian gas consumption (65.6\%) [8]. Natural gas is also used in systems for centralized heating, so that overall share of natural gas for domestic heating and other household

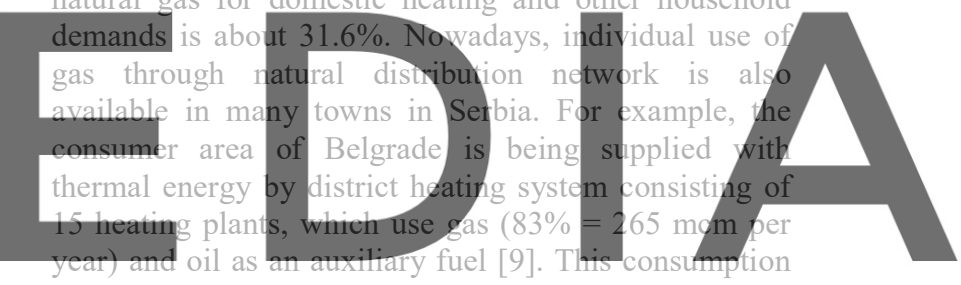
is equal to annual production of natural gas in Serbia.

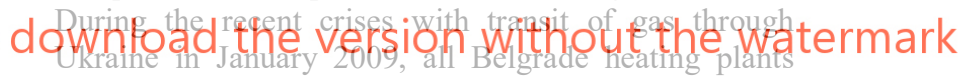
were switched to axially, liquid fuel. Some heating plants in Serbia do not have technical possibilities to substitute gas as operating fuel and these towns such as Novi Sad and Kraljevo had no heating for several days. Serbia has only marginal reserves in underground storage, and with minor indigenous production of gas, without the help from underground storages from Hungary, Austria and Germany situation could be dramatic. Selected place for underground gas storage facility is the Banatski Dvor depleted gas reservoir in Banat with present capacity up to $800 \mathrm{mcm}$. According to the energy strategy, the heat supply for the most Serbian households will be provided by some sort of natural gas heating. Main gas pipeline enables gas import from Russia via Hungary and has the capacity of $6.1 \mathrm{bcm}$ on annual basis, $5.34 \mathrm{bcm}$ while $760 \mathrm{mcm}$ are transported to Bosnia and Herzegovina. 'Srbijagas' is government owned enterprise for natural gas transport. Monopoly in this sector in Serbia still exists. On the other hand, many enterprises exist in natural gas distribution business.

Russia and Serbia signed in 2008 agreement to route a northern pipe of 'South Stream' through Serbia and agreement to create a joint company to build the Serbian 
section of the pipeline and large gas storage facility near Banatski Dvor in Serbia. Often described as a rival to 'Nabucco', 'South Stream' line would run from Russia, across the seabed of the Black Sea to Bulgaria, there to bifurcate: one arm westward via Greece to Italy and another arm northward to Serbia with possible continuation into Central Europe [10-12] (Figure 5).

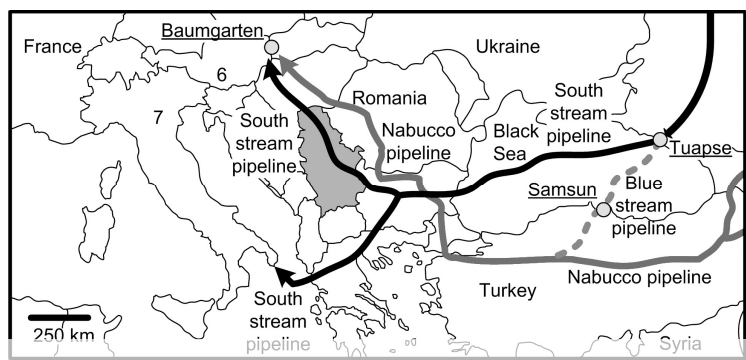

Figure 5. 'South Stream' and 'Nabucco' natural gas pipeline projects.

The main line to Bulgaria is projected to carry $30 \mathrm{bcm}$ of Russian-delivered gas annually, but branch through Serbia will carry $10-18 \mathrm{bcm}$ annually and potentially will be doubled.
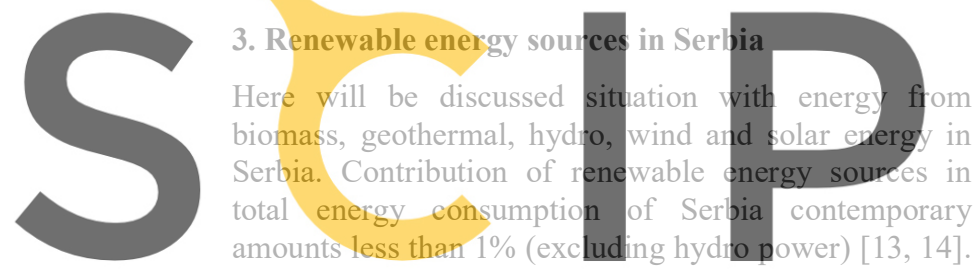
Renewable energy potential in Serbia can cover almost half of its primary energy needs. Utilization of these

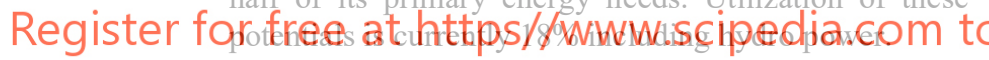

\subsection{Energy from biomass}

With $55 \%$ of its territory being arable land, and $25 \%$ under forests, Serbia has high biomass potentials [1518]. The energy obtained from biomass is a form of renewable energy and utilization of this energy does not add 'new' carbon dioxide, a major greenhouse gas, to the atmosphere, in contrast to fossil fuels. Production of biodiesel in the year 2008 in Serbia was 0.07 million tons $\left(2.9 \cdot 10^{15} \mathrm{~J}\right)$, what is for $133 \%$ higher with respect to the production in the year $2007\left(1.2 \cdot 10^{15} \mathrm{~J}\right)$ [17]. Defining precisely, the organic matter derived from biological organisms (plants and animals) is called biomass. Biomass can be broadly categorized as woody, non-woody biomass and as animal wastes. As the raw materials for bio-ethanol production are seen primarily sugar beet, corn, wheat surpluses, potato surpluses and waste potato, as well as the raw materials intended for these purposes grown on the uncultivated soils, such as hybrid broomcorn, Jerusalem artichoke and triticale. With introduction of new technologies for cultivation and collecting of biomass production of the electrical energy could be raised to $6.4 \mathrm{GWh} / \mathrm{m}^{2}$ per year. Economically feasible biogas production in Serbia is possible to perform only on larger farms. Possible biogas production from swine farms is about 55600 $\mathrm{m}^{3} / \mathrm{m}^{3}$ per year and from bovine farms $39400 \mathrm{~m}^{3} / \mathrm{m}^{3}$ per year. Main reason because of which agricultural husbandries in Serbia do not produce and apply biogas is the lack of corresponding laws and concomitant regulations, low price of electrical energy and indolence for ecological harms, i.e. for possible benefits from production and using of biogas. Yearly production of electric energy in Serbia from biomass could cover less than $5 \%$ of the contemporary consumption. Around $100.8 \cdot 10^{15} \mathrm{~J}$ per year (i.e. around $62 \%$ ) of the whole potential is in the exploitation of the biomass, $42 \cdot 10^{15} \mathrm{~J}$ of which makes the potential of wood biomass (felling of the trees or wood waste mass during its primary and/or industrial processing) and more than $58.8 \cdot 10^{15} \mathrm{~J}$ is made of agricultural biomass. Electrical energy produced by burning the biomass costs in production from $8.70 € c e n t s / k W h$ to $10.23 € c e n t s / k W h$. During the 1980s, 9 biogas facilities were constructed on large swine and bovine farms in Serbia, none of which is now operational.

\subsection{Geothermal energy}

Geothermal energy potential in Serbia is relatively well investigated. The total amount of heat accumulated at

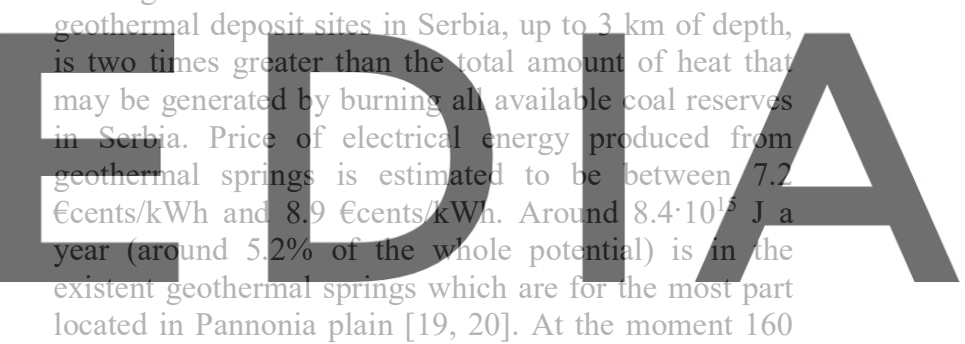

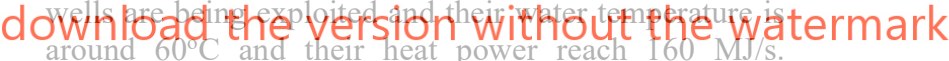
Electrical energy from geothermal springs costs in production from 7.16 €cents/kWh to 8.95 €cents/kWh. Amount of geothermal energy used in residential and commercial areas (direct use) are estimated up to $575 \mathrm{TJ}$ per year for heating with installed capacities up to 18.5 MW. Spas and recreation consumes 1150 TJ per year of thermal energy with installed capacities up to $36 \mathrm{MW}$, grain drying $22 \mathrm{TJ}$ per year with capacity of $0.7 \mathrm{MW}$, greenhouses $256 \mathrm{TJ}$ per year with capacity of $8.4 \mathrm{MW}$, fishing and cattle breeding 211 TJ per year with capacity of $6.4 \mathrm{MW}$, industrial processes $121 \mathrm{TJ}$ per year with capacity of $3.9 \mathrm{MW}$ and heat pump heating only $80 \mathrm{TJ}$ per year with capacity of $12 \mathrm{MW}$. Installed thermal capacities in geothermal energy are $86 \mathrm{MW}$ with annual heating consumption up to 2415 TJ. The application of geothermal energy in balneology can be illustrated by the data that out of more than hundred spas in Serbia, 59 of them utilize thermal water.

There is considerable potential for geothermal energy installation in Serbia that may be used for residential, institutional and industrial applications, which could replace the use of at least half million tons of imported fuels annually. 


\subsection{Hydro energy}

About 1300 micro, mini and small hydro power plants totaling more than $500 \mathrm{MW}$ could be constructed in Serbia, with total production of about $2400 \mathrm{GWh}$ per year. Production of this amount of energy in thermal power plants would require 3.5 million tons of lignite or $0.6 \mathrm{mcm}$ of imported natural gas. The total technical hydropower potential in Serbia is about $17000 \mathrm{GWh}$, out of which about $60 \%$ is currently utilized. Currently, producing energy from hydro-potential is the only way of producing energy from renewable sources that can be measured accurately and that will be recorded in the energy balance sheet of Serbia. Serbia is the country rich in water flows, and the traditional way of getting energy from water is well known here, although not used as much as it should be. Potentials of Danube in Serbia are estimated on 7500 GWh annually and now is only $1000 \mathrm{GWh}$ annually in function. Drina have potentials estimated about $5000 \mathrm{GWh}$ annually and now in function are $3000 \mathrm{GWh}$ annually. The unused potential is situated mainly in the catchments of Drina and Morava rivers and it can be utilized for large as well as for small hydro power plants. The assessment of the technically usable potential of small rivers (facilities for up to $10 \mathrm{MW}$ ) is around $16.8 \cdot 10^{15} \mathrm{~J}$. They represent $10.4 \%$ of the total potential of renqwable sources in Serbia. This estimation is bas small hydro-electric power stin locations suitable for buil $90 \mathrm{~kW} 8.5 \mathrm{MW}$, of the 1590 GW by which around technical potential under $1 \mathrm{MW}$

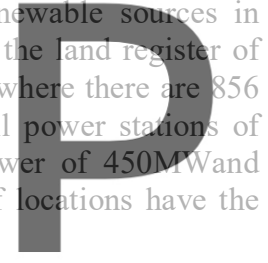

Costs of electrical energy produced in hydro-electric

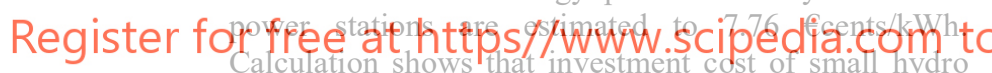
power plants will participate in electricity price average as 4.4 to 9.5 €cents/kWh. This share will be higher for completely new units (4.9-10.4 €cents/kWh), but can be significantly lower (1.3-3.3 €cents/kWh) for small scale hydro units embedding in existing hydro exploitation systems or for reconstruction and rehabilitation of existing systems (0.9-2.5 €cents/kWh). According to presumed annual production pay-back period could be 10 years with electricity price of $6 €$ cents $/ \mathrm{kWh}$. Considering life time of this facilities (more than 50 years) it is clear that relatively high initial investments can bring long-term benefit.

\subsection{Wind energy}

Serbia is the area with significant wind energy potentials. According to research and measurements of wind, the area is rich with wind energy, and the locations in the Pannonia Basin in southern Banat are suitable for the construction of wind plants [21]. The assessment of the wind energy share in the total renewable sources potential is $7.98 \cdot 10^{15} \mathrm{~J}$ annually $(5 \%)$. Based on the taken measurements, Serbia has large potential when it comes to production of energy from these sources, which is shown in figure 6 .
Investing in wind energy is currently also completely dependent on the foreign capital.

Electrical energy from the power of wind costs in production in Serbia between 6.19 €cents/kWh and 9.10 $€$ cents $/ \mathrm{kWh}$. These values are only estimated since a single wind plant in Serbia does not exist.

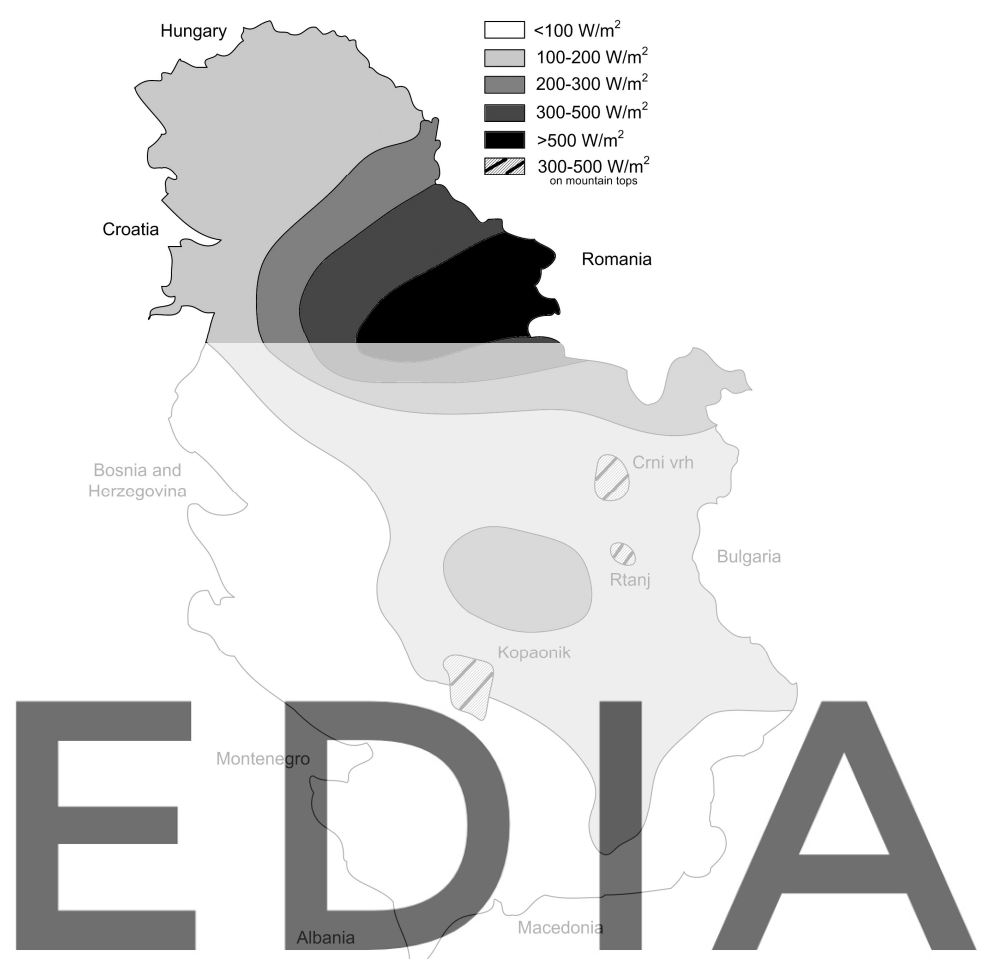

Figure 6. Ayergge wind power at height of $100 \mathrm{~m}$ in Serbia.

Plan for construction of 94 wind power generators, each of $2 \mathrm{MW}$, the construction of substations and electric energy distribution systems as well as other auxiliary facilities necessary for functioning of the system in Banat, exists.

\subsection{Solar energy}

According to the available data, use of solar energy is currently almost negligible in Serbia. A study for installation of solar panels in Belgrade municipal heating company (in Serbian, JKP 'Beogradske Elektrane") in heating plant 'Cerak', with a capacity of $1.88 \mathrm{MW}$ is being 45 investigated. 'Cerak' plant is fuel by natural gas primarily [22]. Effects of solar panel in 'Cerak' are: reduction of combustion gases emission, particularly $\mathrm{CO}_{2}$ for the amount of 1400 tons annually and substitution about $430 \mathrm{tcm}$ (thousand cubic meters) of natural gas during the summer period and about 240 tcm during the winter period with total amount approximately $670 \mathrm{tcm}$ of natural gas annually. Preliminary results show that over $160000 €$ could be saved per year in natural gas costs, and that the investment would pay off in the 5.6 years. The assessment of the solar energy share in the total renewable energy sources potential is $26.88 \cdot 10^{15} \mathrm{~J}$ 
annually $(16.7 \%)$, with the planned estimation that every housing unit install approximately $4 \mathrm{~m}^{2}$, which would represent in total 10.6 million $\mathrm{m}^{2}$. Most of the territory of Serbia the number of sunny days is significantly higher than in many European countries; over 2000 h, i.e. 2071 h in Belgrade, 2159 h in Novi Sad and $2156 \mathrm{~h}$ in Priština. Scheme of daily average of global solar energy on horizontal plane in Serbia is shown in figure 7.

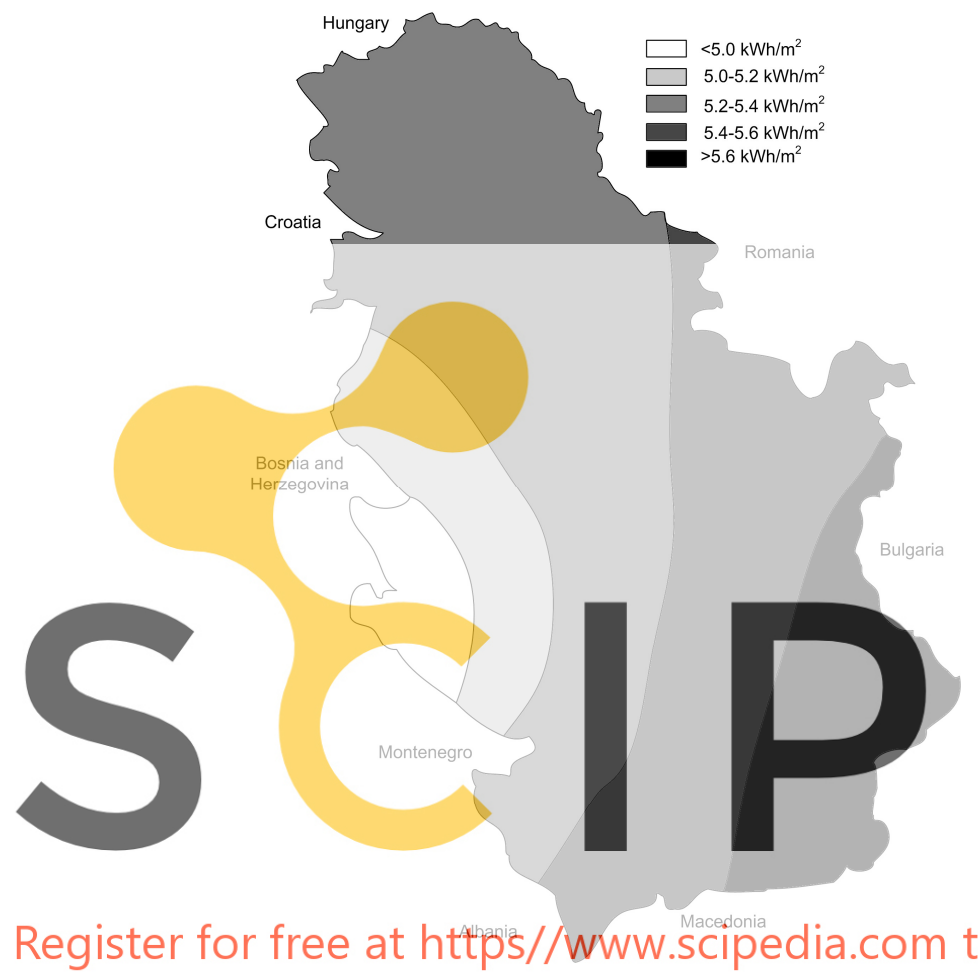

Figure 7. Average solar energy in Serbia on horizontal plane.

Electrical energy from photovoltaic systems costs in Serbia in production $48.1 €$ cents/kWh.

Solar radiation in Serbia is sufficient for efficient exploitation even during winter months. Commercial types of solar collectors may annually yield from 1.2 to $3 \mathrm{kWh}$ of energy per day per square meter depending on the period of the year and the location of a consumer. Consequently, one square meter collector of solar energy may transfer to the consumer heat energy from 36 to $90 \mathrm{kWh}$ per month. By using of such installations, it is possible to cover $50-60 \%$ of the annual energy consumption for domestic heating. Energy requirements for sanitary water are covered up to $80 \%$ in the period April-October and about 30\% in period October-April.

\section{Final energy consumption in Serbia}

Lignite is the only mineral fuel in Serbia comparable to the EU-27 potential. Serbian lignite potential is the largest, after Germany, in Europe [23]. Lignite production in Serbia is used dominantly for electricity generation. On the other hand, Serbia signed oil and gas agreement with Russia [7, 8, 24, 25]. While lignite is dominant fuel for electricity production, natural gas is dominant fuel for district heating in Serbian towns [6].

\subsection{Electricity production and consumption}

Before NATO campaign in March 1999, Serbia was self-sufficient in electricity produced from coal and hydropower, and electricity normally covered $75 \%$ of the total centrally supplied energy needs of Serbia (gas and oil cover the remaining $25 \%$ of demand). In electricity sector the most important and the greatest participants are the Serbian Electric Power Industry (EPS, in Serbian: Elektroprivreda Srbije). EPS development in Serbia began in 1881, when the first open-air restaurant in Belgrade was lit by direct current lamp. The first power plant in Serbia was started up in 1884. However, the beginning of electrification in Serbia is considered to be 6 October 1893 (the first public electric thermal power plant was put into operation in Belgrade). The first long distance transmission line in Serbia, $17 \mathrm{~km}$ long, was put into operation in 1903. One of the biggest thermal power plants in the Balkans, was built in Belgrade in 1933. Serbian EPS was founded in 1945, after World War II. 'Bajina Bašta' hydroelectric power plant was put into

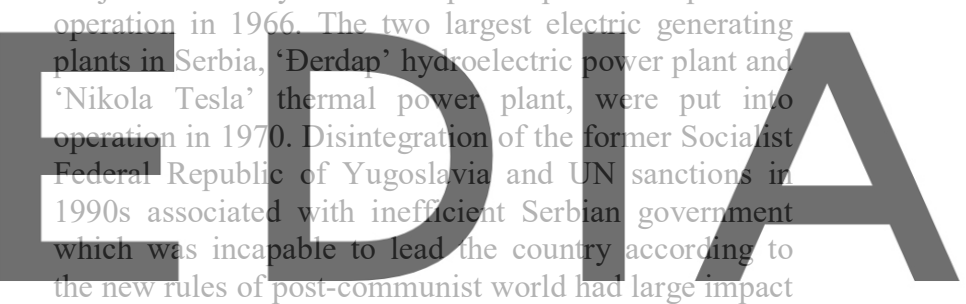
on further development of the Serbian electric power

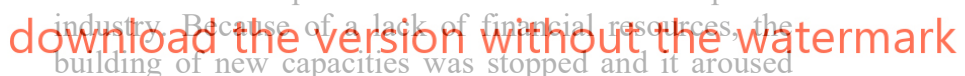
the maintenance problem of existing electric generating and transmission capacities. After the reforms in 2005, new enterprise Serbian Power Transmission Company (EMS, in Serbian Elektro Mreže Srbije), previously part of EPS, was established. According to the Energy Law from 2004, the Serbian Government issued a decree on founding the public enterprises: the Serbian Electric Power Industry (EPS) and the Serbian Power Transmission Company (EMS). The decrees on founding the two above mentioned public enterprises became valid on 7 July 2005. The Serbian EPS is authorized for generation and distribution of electricity, distribution system management, electric power sale and coal production and processing, while the main activities of EMS are electric power transmission, transmission system management and electric power market management. Both of them are $100 \%$ owned by the Republic of Serbia. The enterprises for power generation and coal production are: Nikola Tesla (Obrenovac) - thermal power plant, Kostolac (Kostolac) - thermal power plant and coal mining basin, Pannonian electric power plants (Novi Sad) - combined heat and power plants, Đerdap (Kladovo) - hydro power plant, Drinsko-Limske hydro power plants, Kolubara 
(Lazarevac) - coal mining basin, and Kosovo (Obilić) coal mining basin and thermal power plant (now under UN jurisdiction)

The total power capacity of the Serbian EPS is $8.3 \mathrm{GW}$ $[26,27]$. Thermal power capacities provide it with $65 \%$, while hydroelectric power makes up almost $44 \%$ of total electric power capacity [28]. The thermal power capacity of the Serbian EPS consists of eight thermal power plants of total installed power amounting to 5.1 GW which rely on lignite, as well as three combined heat and power plants of total installed power amounting to $353 \mathrm{MW}$ which rely on liquid and gas fuels. In the Serbian electric power system, there are nine hydroelectric power plants, with 50 hydro generating sets, the total power of which amounts to 2.8 GW [261. Besides this, the Serbian EPS onerates with three power plants (HPP Piva, HPP Gazivode and Heating Plant Belgrade) that are not in its ownership. These have total capacity of $461 \mathrm{MW}$. The largest group of final power consumers is the household sector with $55.3 \%$, then the industry sector with $22.4 \%$ and then other consumers. If government does not take the decision for building new thermal power plants, Serbia will have a shortage of electric power. Previous plan, before 2000, was to build five nuclear power plants. This plan failed. Serbia still does not have regutation on electric power generatio sources beside hydro pow r. sites suitable for constructi power plants of power would make it possible 455 MW. That amount of Belgrade, and in terms of generated energy it would be almost possible to supply Belgrade for two months. In

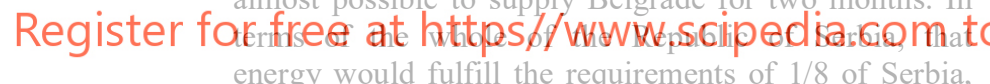
energy would fulfill the requirements of $1 / 8$ of Serbia,
and in terms of energy amounts, would fulfill requirements for 15 days in Serbia. Average electricity tariff for electricity in Serbia is 29.2 €/MWh [29].

The electric power distribution system consists of high voltage system amounting to $400 \mathrm{kV}, 220 \mathrm{kV}$, and $110 \mathrm{kV}$. Electric power distribution operates under a monopoly, but electric power sale will be subject to the market in the future $[30,31]$.

Both, EPS and EMS are typical example of Serbian post-communist firms under Government's jurisdiction, i.e. both have too many inefficient employees with very high salaries. Now, it is almost impossible to be hired in such firms but also on the other hand already employed practically cannot be fired.

\subsection{Domestic heating}

From 1978 to 2002 the relative changes in consumption of natural gas, electricity, liquid fuels, and coal in the world were $133.5 \%, 74.3 \%,-35.2 \%$ and $-85.2 \%$, respectively. Natural gas is today the most favorable fuel for domestic heating in Serbia. Thorough study for implementation of gas oriented heating in urban areas had been conducted in Serbia. Brkić and Tanasković [6] concluded that district-heating system fueled by gas is a better option in areas with small built-up density, but with skyscrapers while a gas distribution system is a better option in areas with high density of individual houses (in this case gas distribution system is significantly in advance). These conclusions are quantified in the paper of Brkić and Tanasković [6]. Model can be applied also for conditions in other countries. The strategy for heating of dwellings in urban areas of Serbia, since the communist period, had been made to favor district heating systems. Today, most of these plants use gas as main fuel. Nowadays, individual usage of gas through natural distribution network is also available in many towns in Serbia. Belgrade has district heating system consisting of 15 heating plants. Their annually gas consumption is about $265 \mathrm{mcm}$. This consumption is equal to annual production of natural gas in Serbia. Central district heating in Serbia is inefficient and mostly obsolete.

Before 2008, the sector of gas and oil was dominated by state-owned monopoly NIS (in Serbian, Naftna Industrija Srbije) with central office in Novi Sad. According to the Energy Law, from October 2005, old NIS was split into two major sectors: oil (new NIS and 'Transnafta') and gas ('Srbijagas'). Gas sector was

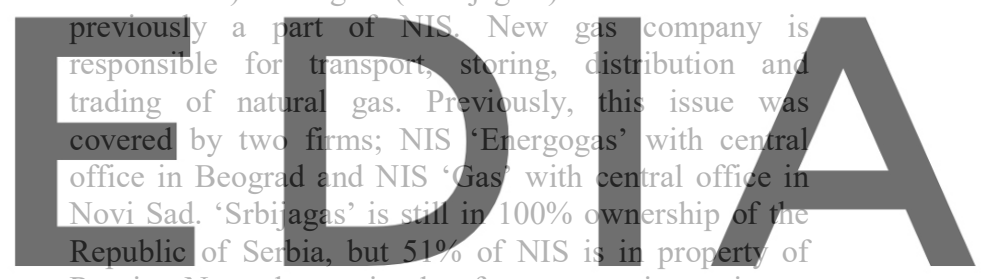
Russia. Natural gas is the fastest growing primary energy source in Serbia. New oil and gas agreement,

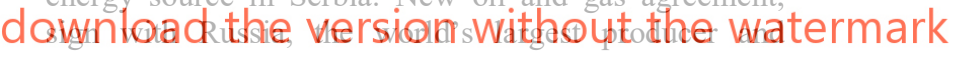
transporter of natural gas, will transform Serbia from an only import country to a transit country for Russian gas. According to that, natural gas in Republic Serbia is expected to be the primary substitute for electricity based heating either through district heating in densely populated areas or individual boilers in the rest of the country. Today, Serbian 'Srbijagas', is good example of big post-communist enterprise with too many inefficient employees [8]. Government strategy is to keep all existing working positions. This leads to increasing of inefficiency and also to the highest unemployment rate among the almost all European countries. Highly educated young population is the main victim of these circumstances. Today practically is impossible to be hired in 'Srbijagas', even for high-educated experts [8]. Informal prohibition for hiring and also for dismissing from a job exists from 2002.

\section{Energy legislative in Serbia}

Di Vita [32] classified Serbian civil law in German model. German system ensures the best creditor protection, followed by the Scandinavian and the worst protection is that of the French. 
Serbia started establishing the new legal, institutional and regulatory framework for the energy sector in order to create a viable and efficient energy market environment through licensing, pricing and energy services control by an independent regulatory body. The new Energy Law was enforced in 2004.

The main state authorities involved in the Serbian energy sector are the following:

- Ministry of Mining and Energy is charged by Republic of Serbia with governmental affairs regarding: electricity power sector, geology and mining sector, oil and gas sector, general energy sector, etc.

- Ministry of Science and Technological Development is responsible for Research and Science Institutions. This Ministry manages National Energy Efficiency Programs.

- Serbian Energy Regulatory Agency was established in June 2005. The Agency was established as a regulatory body for performing the following tasks: enhancing and directing the development of the energy market in accordance with the principles of non-discrimination and effective competition. The activities of the Energy Agency are determining tariff systems for calculating electricity and natural gas prices for tariff systems for access power transmission determining tariff methods for calculating electricity
and natural gas prices. The Energy A gency adopted a methodology for determination of tariff elements.

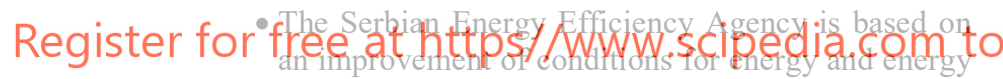
products conservation, as well as efficiency increases in energy conservation in all sectors of consumption.

\section{Conclusions}

Serbia started real transition process in 2000. Prior to these changes, the Serbian economy and energy sector had been subjected to the well known unfavorable conditions such as civil war in former Yugoslavia, UN sanctions and blockade under UNSC Resolution 757, world record in hyperinflation in 1993, NATO military campaign in 1999, undemocratic regime before 2000, difficult situation in the south province of Kosovo and Metohija, problem in functionality of former union with Montenegro, many Serbian refugees exiled from Croatia and from south province of Kosovo and Metohija, etc. During that period, technical performance of energy infrastructure considerably deteriorated, while the economic capability to secure energy supply, reliable and efficient operation, and regular energy system maintenance, had considerably declined. Energy companies have been too far from financially sustainable operation.
Today, Serbia does not control all its territory. Similar situation is with Cyprus which is already full member of EU [33]. It seems that such situation in south Serbian autonomous province is not obstacle for integration in EU. But Serbia produces most of electricity from lignite, and large reserves are in the territory of Kosovo and Metohija. Lignite reserves in central Serbia are now enough to satisfy current electricity demands. New capacities and modernization of existing capacities in thermal plants will be demandable very soon.

Serbian energy expert experienced all four stages explained in the paper of Bardi [34] regarding to almost all possible energy sources used or planned to be used for domestic heating and electricity production (1. Never heard of it, 2. It is wrong, 3. It is right, but irrelevant, 4. It is what I had been saving all along). For example gas production decreased constantly since 1993, but gas was always taken into account as major heating source. Now, all hopes in gas oriented heating are connected with gas agreement with Russia. Before gas, Serbian energy experts favor electricity oriented heating. Main electricity source for such heating was planned to be from nuclear energy. Five nuclear plants were planned for that purpose in Serbia. Today, situation is opposite. Gas is favored fuel for heating and

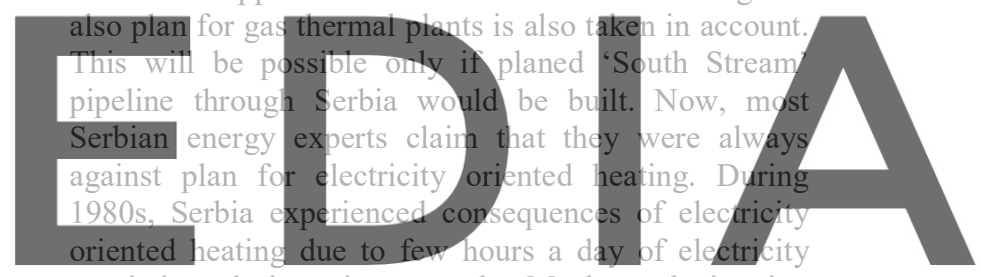
restrictions during winter months. Maybe such situation will be with gas in next few years.

\section{download the version without the watermark} common practice in Serbia. Serbia does not have enough indigenous production for such purpose and only solution is import of gas. Time will show if such import will be sustainable since natural gas consumption is increasing all over the world $[35,36]$.

Renewable energy sources have significant roles in the world, but their share in Serbian energy production excluding hydro sources is minor $[37,38]$. Serbia still does not have plan for $\mathrm{CO}_{2}$ emission. Serbia with emission of 53.32 million tons annually is ranged as 55 among 207 sovereign states (amount of $\mathrm{CO}_{2}$ emission in Serbia also can be calculated according to the procedure shown in the paper of de la Rue du Can and Price [39]).

Sustainable energy development has a goal to integrate economic, ecological, social and institutional subsystem into a whole, taking care of their mutual influence [40, 41]. Serbia is yet far away to accomplish this [42].

\section{References}

[1] Hirt S. (2009). Belgrade, Serbia. Cities, vol. 26(5), pp. 293-303. 
[2] Ercegovac M., Životić D., Kostić A. (2006). Genetic-industrial classification of brown coals in Serbia. International Journal of Coal Geology, vol. 68(1-2), pp. 39-56.

[3] Rizaj M., Beqiri E., McBow I., O’Brien E.Z., Kongoli F. (2008). The mineral base and productive capacities of metals and non-metals of Kosovo. $J O M$, vol. 60(8), pp. 18-22.

[4] Daničić D., Mitrović S., Pavlović V., Kovačev S. (2009). Sustainable development of lignite production on open cast mines in Serbia. Mining Science and Technology, vol. 19(5), pp. 679-683.

[5] Cardu M., Ionel I., Ungureanu C. (2005). Ecological aspects concerning the combustion of lignite in Romanian thermonower plants. Energy Conversion and Management, vol. 46(9-10), pp. $1645-1654$.

[6] Brkić D., Tanasković T.I. (2008). Systematic approach to natural gas usage for domestic heating in urban areas. Energy, vol. 33(12), pp. 1738-1753.

[7] Brkić D. (2008). Transportation: Serbian, Russian pipeline accord enhances European gas security. Oil \& Gas Journal, vol. 106(48), pp. 52-54.
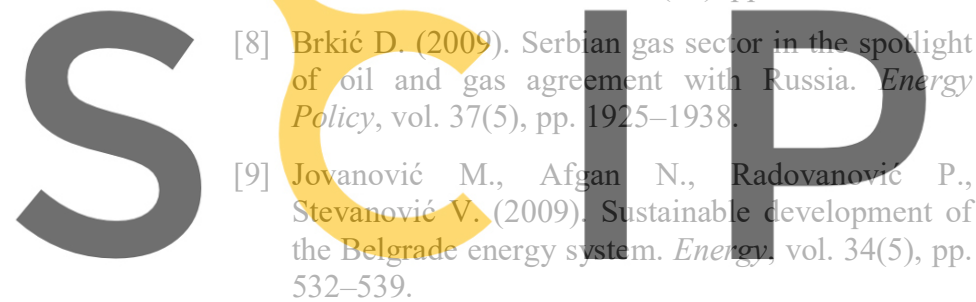

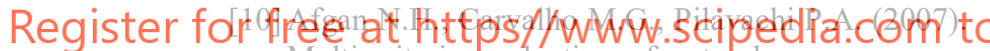
Multi-criteria evaluation of natural gas resources. Energy Policy, vol. 35(1), pp. 704-713.

[11] Afgan N.H., Carvalho M.G., Pilavachi P.A., Martins N. (2007). Evaluation of natural gas supply options for south east and central Europe. Part 1: Indicator definitions and single indicator analysis. Energy Conversion and Management, vol. 48(9), pp. 2517-2524.

[12] Afgan N.H., Carvalho M.G., Pilavachi P.A., Martins N. (2008). Evaluation of natural gas supply options for Southeast and Central Europe. Part 2: Multi-criteria assessment. Energy Conversion and Management, vol. 49(8), pp. 2345-2353.

[13] Golušin M.T., Tešić Z., Ostojić A. (2010). The analysis of the renewable energy production sector in Serbia. Renewable and Sustainable Energy Reviews, vol. 14(5), pp. 1477-1483.

[14] Munitlak Ivanović O.D., Golušin M.T., Dodić S.N., Dodić J.M. (2009). Perspectives of sustainable development in countries of Southeastern Europe. Renewable and Sustainable Energy Reviews, vol. 13(8), pp. 2079-2087.
[15] Dodić S.N., Popov S.D., Dodić J.M., Ranković J.A., Zavargo Z.Z. (2009). Potential contribution of bioethanol fuel to the transport sector of Vojvodina. Renewable and Sustainable Energy Reviews, vol. 13(8), pp. 2197-2200.

[16] Dodić S.N., Popov S.D., Dodić J.M., Ranković J.A., Zavargo Z.Z. (2009). Potential development of bioethanol production in Vojvodina. Renewable and Sustainable Energy Reviews, vol. 13(9), pp. 2722-2727.

[17] Dodić S.N., Popov S.D., Dodić J.M., Ranković J.A., Zavargo Z.Z., Golušin M.T. (2010). An overview of biomass energy utilization in Vojvodina. Renewable and Sustainable Energy Reviews, vol. 14(1), pp. 550-553.

[18] Dodić S.N., Vučurović D.G., Popov S.D., Dodić J.M., Zavargo Z.Z. (2010). Concept of cleaner production in Vojvodina. Renewable and Sustainable Energy Reviews, vol. 14(6), pp. 16291634.

[19] Golušin M.T., Munitlak Ivanović O.D., Bagarić I., Vraneš S. (2010). Exploitation of geothermal energy as a priority of sustainable energetic

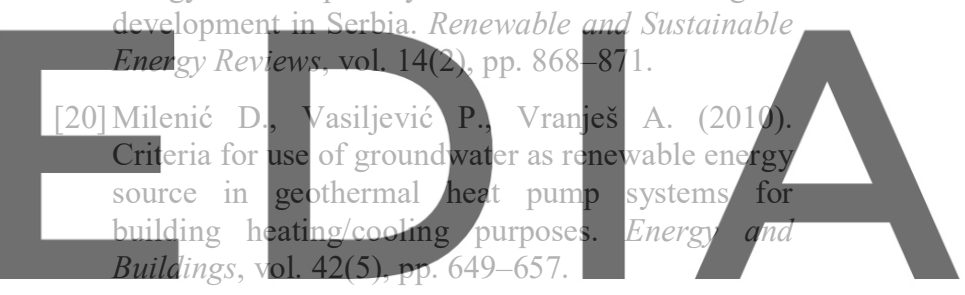

[21] Josimović B., Pucar M. (2010). The strategic

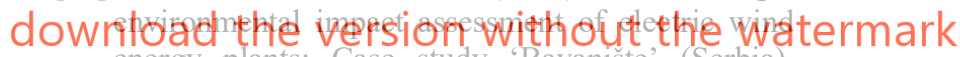
energy plants: Case study 'Bavaniste' (Serbia). Renewable Energy, vol. 35(7), pp. 1509-1519.

[22] Turanjanin V., Bakić V., Jovanović M., Pezo M. (2009). Fossil fuels substitution by the solar energy utilization for the hot water production in the heating plant "Cerak" in Belgrade. International Journal of Hydrogen Energy, vol. 34(16), pp. 7075-7080.

[23] Sames C.W. (2008). Enlargement: The mineral production of Turkey and the Western Balkans in comparison with the EU-27. Minerals \& Energy, vol. 23(4), pp. 177-183.

[24]Fernandez R. (2009). Russian gas exports have potential to grow through 2020. Energy Policy, vol. 37(10), pp. 4029-4037.

[25] Deitz L., Stirton L., Wright K. (2009). South East Europe's electricity sector: attractions, obstacles and challenges of Europeanisation. Utilities Policy, vol. 17(1), pp. 4-12.

[26] Jednak S., Kragulj D., Bulajić M., Pittman R. (2009). Electricity reform in Serbia. Utilities Policy, vol. 17(1), pp. 125-133. 
[27] Maruyama N., Eckelman M.J. (2009). Long-term trends of electric efficiencies in electricity generation in developing countries. Energy Policy, vol. 37(5), pp. 1678-1686.

[28] Lehner J., Weißbach T. (2009). Global and local effects of decentralised electric power generation on the grid in the Western Balkan Countries (WBC). Energy, vol. 34(5), pp. 555-563.

[29] Georgio P., Tourkolias C., Diakoulaki D. (2008). A roadmap for selecting host countries of wind energy projects in the framework of the clean development mechanism. Renewable and Sustainable Energy Reviews, vol. 12(3), pp. 712-731.

[30] Vailati R. (2009). Electricity transmission in the energy community of South East Europe. Utilities Policy, vol. 17(1), pp. 34-42.

[31] Koroneos C.J., Nanaki E.A. (2007). Electric energy sustainability in the Eastern Balkans. Energy Policy, vol. 35(7), pp. 3826-3842.

[32] Di Vita G. (2008). Differences in pollution levels among civil law countries: A possible interpretation. Energy Policy, vol. 36(10), pp. 3774-3786.

[33] Pilavachi P.A., Kalampalikas N.G., Kakouris M.K., Kakaras T., Giannakopoulos D. (2009). The energy policy of the Republic of Cyprus. Energy, vol. 34(5), pp. 547-554.

[34] Bardi U. (2009). Peak oil: The four stages of a new idea. Energy, vol. 34(3), pp. 323-326.

[35] Afgan N.H., Al Gobaisi D., Carvalho M.G., Cumo M. (1998). Sustainable energy development.
Renewable and Sustainable Energy Reviews, vol. 2(3), pp. 235-286.

[36] Lund H., Moller B., Mathiesen B.V., Dyrelund A. (2010). The role of district heating in future renewable energy systems. Energy, vol. 35(3), pp. 1381-1390.

[37] Chien T., Hu J.-L. (2008). Renewable energy: An efficient mechanism to improve GDP. Energy Policy, vol. 36(8), pp. 3045-3052.

[38]Bojić M. (2004). Education and training in renewable energy sources in Serbia and Montenegro. Renewable Energy, vol. 29(10), pp. 1631-1642.

[39] de Ia Rue du Can S., Price L. (2008). Sectoral trends in global energy use and greenhouse gas emissions. Energy Policy, vol. 36(4), pp. 13861403.

[40] Golušin M.T., Munitlak Ivanović O.D. (2009). Definition, characteristics and state of the indicators of sustainable development in countries of Southeastern Europe. Agriculture, Ecosystems and Environment, vol. 130(1-2), pp. 67-74.

[41] Mihajlov A. (2010). Opportunities and challenges for a sustainable energy policy in SE Europe: SE European Energy Community Treaty. Renewable and Sustainable Energy Reviews, vol. 14(2), pp. 872-875.

[42] Thomaidis F., Konidari P., Mavrakis D. (2008). The wholesale natural gas market prospects in the energy community treaty countries. Operational Research International Journal, vol. 8(1), pp. 6375. 